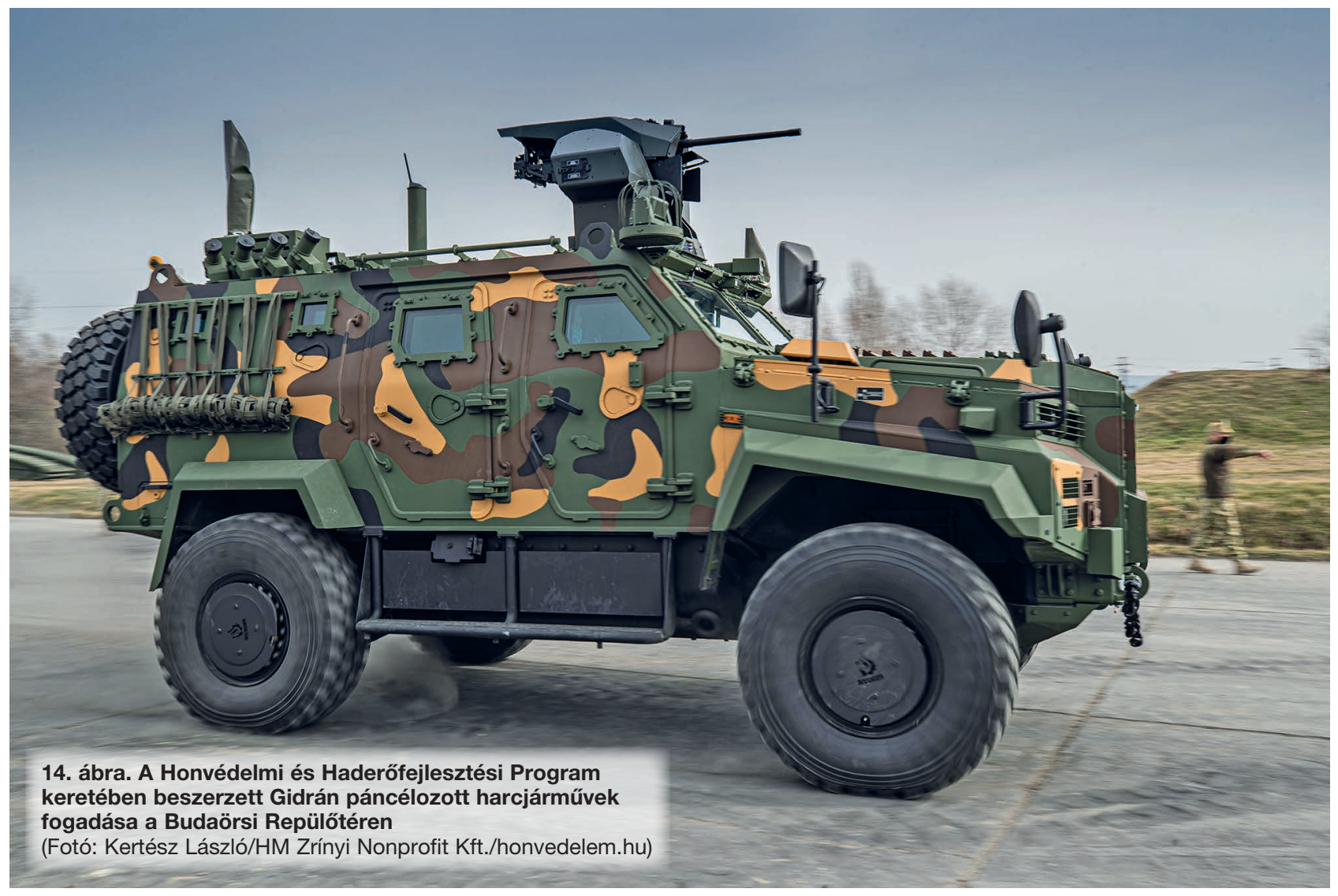

Ocskay István* - Vágner Szabolcs**

\title{
Gidrán - egy növelt aknavédelemmel rendelkező harcjármű megjelenése a Magyar Honvédségben m.resz
}

\begin{abstract}
A Magyar Honvédség új beszerzésű, növelt aknavédelemmel rendelkező harcjárműve jelentős mértékben csökkenti azokat a harctéri veszteségeket, amelyeket az improvizált robbanó eszközök okozhatnak a hagyományos kialakítású harcjármüvekben. A szerző, tanulmányának első részében nemzetközi (iraki, afrikai, afganisztáni stb.) példák segítségével felidézte a növelt aknavédelemmel rendelkező jármúvek történetét, majd bemutatta a járműépítéssel foglakozó török Nurol Makina gyárat. A második rész részletesen kitér az üzem által gyártott harcjármútípusokra, majd bemutatja az Ejder Yalçin (4×4) típusú Block 4. verziót, amelyet a Magyar Honvédségben Gidrán néven rendszeresítettek.
\end{abstract}

\section{A NuRol Makina MRAP termékeI}

A Nurol Makina A.Ș. vállalat első katonai terméke a román Romarm S.A. állami vállalattal közösen készített RN-94 típusú, $6 \times 6$ hajtásképletű páncélvédett jármű volt, amelynek minden elemét az ankarai telephelyen tervezték, fejlesztették és gyártották. Az első prototípus - amelyet Romániában tartós teszteknek vetettek alá - 1995-ben készült. A próbaidőszak tapasztalatai alapján épített további $5 \mathrm{db}$ eszközt 1997-ben a török hadsereg sikeresen tesztelte (15. ábra), de végül az FNSS gyártotta Pars kerekes harcjárműcsalád $6 \times 6$ és $8 \times 8$ hajtásképletű járműveit rendszeresítette alakulatainál. [15]

\footnotetext{
* Ezredes, MH Modernizációs Intézet, parancsnokhelyettes, K+F igazgató, NKE HHK Katonai Műszaki Doktori Iskola, doktorandusz. ORCID: 0000-0003-0279-8215

** Őrnagy, MHP Haderőtervezési Csoportfőnökség, Szárazföldi Hadfelszerelési Rendszerek Fejlesztési Főnökség, főtiszt. ORCID: 0000-0002-8889-3936
} 


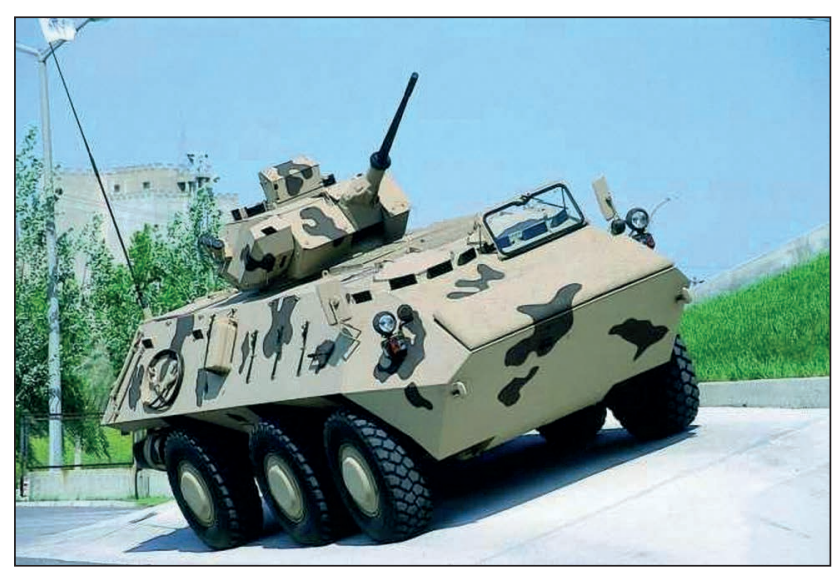

15. ábra. Egy, a török teszteken részt vevő RN-94-es páncélozott harcjármü [17]

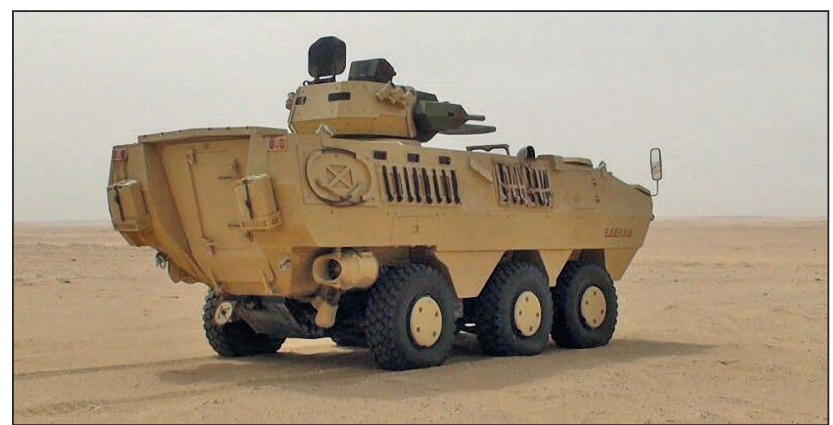

16. ábra. Egy Ejder $6 \times 6$ páncélozott szállító harcjármú sivatagi terepen [18]

A mintegy 13 tonnás harcjárműből végül egyedül Banglades rendelt meg $9 \mathrm{db}$ egészségügyi kiürítő változatot 2005-ben.

Az RN-94-essel nyert tapasztalatok alapján, még 2005ben az osztrák Steyr-Daimler-Puch of Austria vállalattal kötöttek licencszerződést a Pandur-II harcjárművek törökországi gyártására, de a török hadsereg igényei azt diktálták, hogy török tervezéssel és gyártással készüljenek el a harcjárművek, a legkevesebb külföldi beszállítói kitettséggel. Ezen követelmények figyelembevételével került sor a vállalat első saját tervezésű és gyártású harcjárműve, az Ejder $6 \times 6$ harcjármű gyártáselőkészítésére. Az RN-94 típusú páncélozott szállító harcjármű tervezésével és gyártásával nyert tapasztalatokat jól hasznosították a vállalat első növelt aknavédelemmel rendelkező harcjárművének gyártása során, amelyre a török hadsereg igénye alapján 2006ban került sor. A sikeres teszteket a hadsereg és a biztonsági szolgálatok megrendelései követték, amelyek teljesítése érdekében szükséges volt olyan gyártósor összeállítsa, amely alkalmas páncéllemezek hideghajlítására nagyobb dimenziókban is. Ebből a célból vásárolták azt a 2000 tonnás hidegen hajlító gépet is, amelynek mérete lehetővé teszi nemcsak a $4 \times 4$, hanem a $6 \times 6$, sőt a $8 \times 8$ hajtásképletű páncélozott harcjárművek oldalpáncéljának egyhosszban történő hajlítását is. Az Ejder ${ }^{21} 6 \times 6$ harcjármü gyártásához szükséges további szerszámgépek - így az öttengelyes lézervágók és marógépek, valamint a héttengelyes hegesztőgépek - beszerzésére is ekkor került sor. Az Ejder 6×6 harcjárművek gyártása 2009 februárjában az örmény belbiztonsági erők megrendelésére, 72 db harcjármü legyártásával indult meg. Egy ilyen típusú harcjármü sivatagi tesztje látható a 16. ábrán.

A vállalat az Ejder sikerén felbuzdulva további, más feladatokra is alkalmas - többek között Ejder Yalçin, NMS növelt aknavédelemmel rendelkező harcjárművet, ILGAZ II belbiztonsági járművet, Ejder Toma tömegoszlató járművet, vagy az Ejder Kunter hegyvidéki körülményekre optimalizált különleges rendeltetésű - páncélozott járművet gyárt a hazai és a nemzetközi piacra.

\section{Az EJder YaLÇIN JÁRMÜVEK FEJLESZTÉSE}

A török hadsereg, illetve a koalíciós csapatok által a különféle hadműveletek és béketámogató feladatok során nyert tapasztalatok, illetve a hazai újrafogalmazott követelmények kielégítése érdekében 2012-ben a Nurol Makina vállalat megkezdte az újgenerációs, növelt aknavédelemmel rendelkező harcjárművek tervezését Ejder Yalçin név alatt, amelyeknek alkalmasaknak kellett lenniük a városi és a hagyományos hadviselés körülményei között történő alkalmazásra is.

A jármű fejlesztésének evolúcióját szemlélteti a 17. ábra, amely alapján négy különböző verziót különböztethetünk

\section{7. ábra. Az Ejder Yalçin MRAP jármű fejlesztésének lépcsőfokai a tervezéstől napjainkig (Forrás: szerzői szerkesztés)}

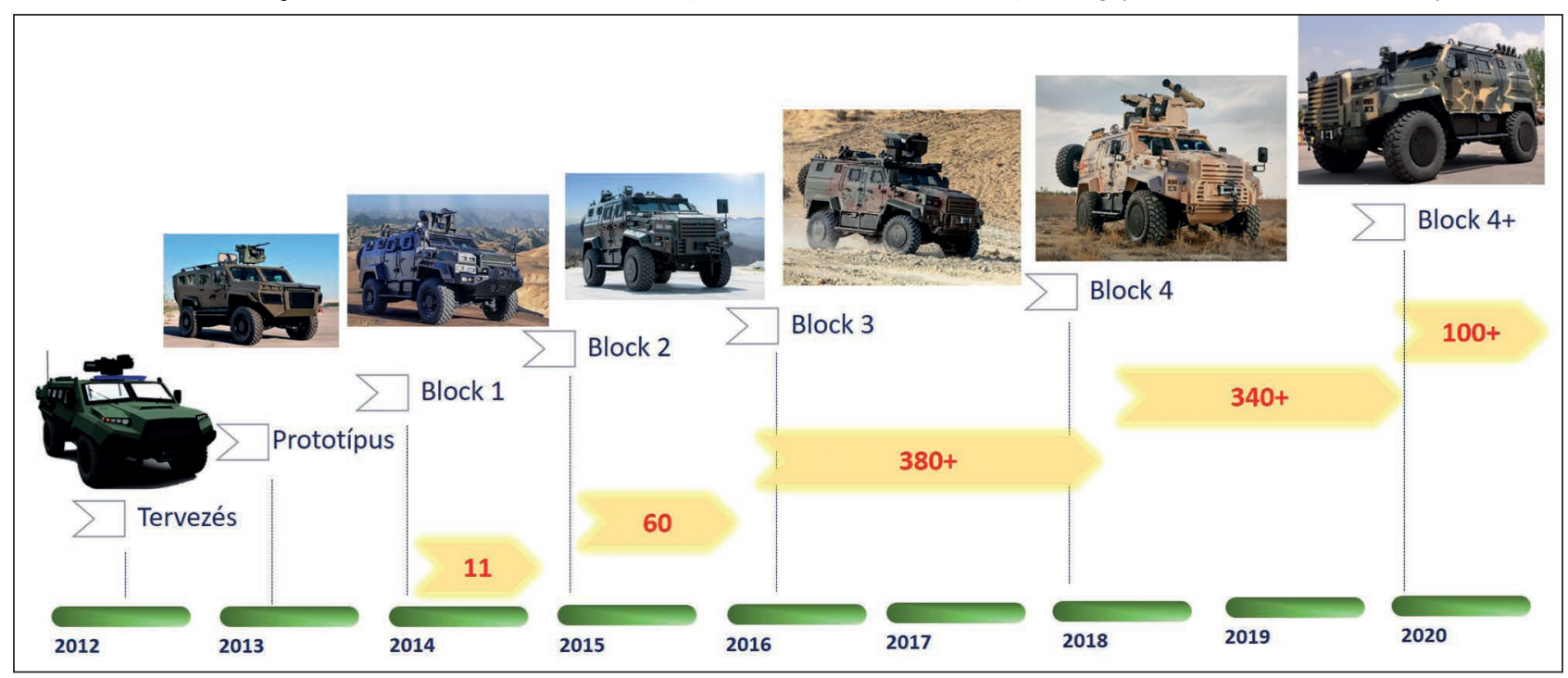




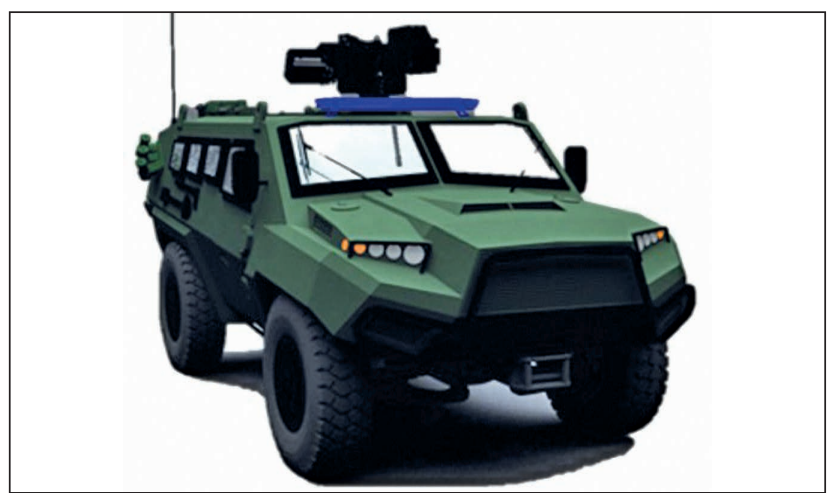

18. ábra. Az Ejder Yalçin harcjármú számítógépes terve 2012-böl (Forrás: Nurol Makina)

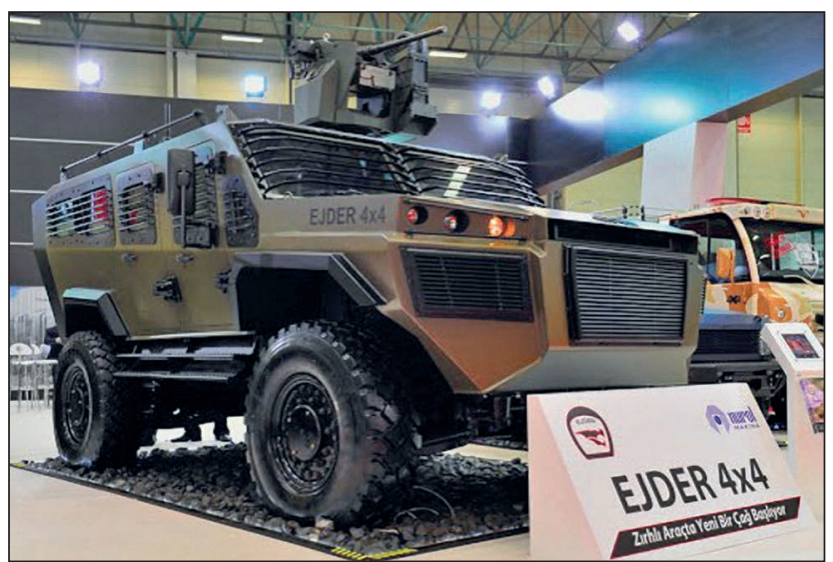

19. ábra. Az Ejder Yalçin harcjármű prototípusa az IDEF'13 kiállításon Isztambulban [19] meg a jármű korszerűsítése és gyártása során. Lássuk, hogy ezek a változatok, amelyeket „Block”-ként emlegetnek, miben is térnek el egymástól, és melyek azok főbb jellemzői!

A 2012 novemberében megkezdett tervezést követően, 2013-ra elkészült a jármű prototípusa, amelyből egy példányt már a 2013 nyarán Isztambulban megrendezett IDEF'13 (International Defence Industry Fair) nemzetközi védelmi ipari vásáron bemutattak. A tervezés nagymértékben alapult a korábbi $6 \times 6$ kerékképletű Ejder $6 \times 6$ járműre, de a konstruktőrök alapvetően a HMMWV és az MRAP kategóriák közötti igények kielégítésére fókuszáltak. Céljuk a nagy sebességü feladatvégrehajtás, illetve az ehhez köthető lehető legnagyobb hasznos teherbírás párosítása volt, amellyel a különleges műveleti erők $\left(\mathrm{SOF}^{22}\right)$ által támasztott követelményeket tartották szem előtt. A jármű tervét a 18. ábra szemlélteti, míg ehhez képest az isztambuli kiállításon bemutatott harcjármű jelentős eltérést mutat, ahogy az a 19. ábrán is látható.

2014-ben készült el a mai Ejder Yalçin harcjármű ősének számító Block 1. harcjármű, amelyből alapvetően tesztelési és koncepciófejlesztési céllal gyártottak 11 db-ot a török rendőrség különleges műveleti egységei számára, a szintén török Aselsan A.Ș. vállalat által gyártott SARP ${ }^{23}$ távirányított toronnyal szerelve.

Az első sorozatgyártásra érett jármű a 2015-ben bemutatkozó Block 2. volt. E jármű építése során már felhasználták mindazokat a hadműveleti környezetben nyert tapasztalatokat is, amelyeket az előző tesztszériával szereztek. Ezek alapján lecserélték a korábban alkalmazott, 222 kW (300 LE) teljesítményű motort egy soros elrendezésű, hathengeres, $259 \mathrm{~kW}$-os (350 LE-s) Cummins dízelmotorra, ezzel növelve a 14 tonnás jármű teljesítménydotációját és nyomatékát is. A hegyvidéki terepen nyert tapasztalatok alapján erősebb motorfékkel és retarderrel ${ }^{24}$ látták el a jár-

20. ábra. Az Ejder Yalçin Block 2. harcjármű egy változata az Aselsan vállalat gyártotta SARP típusú, távirányított toronnyal szerelve (Forrás: Nurol Makina)

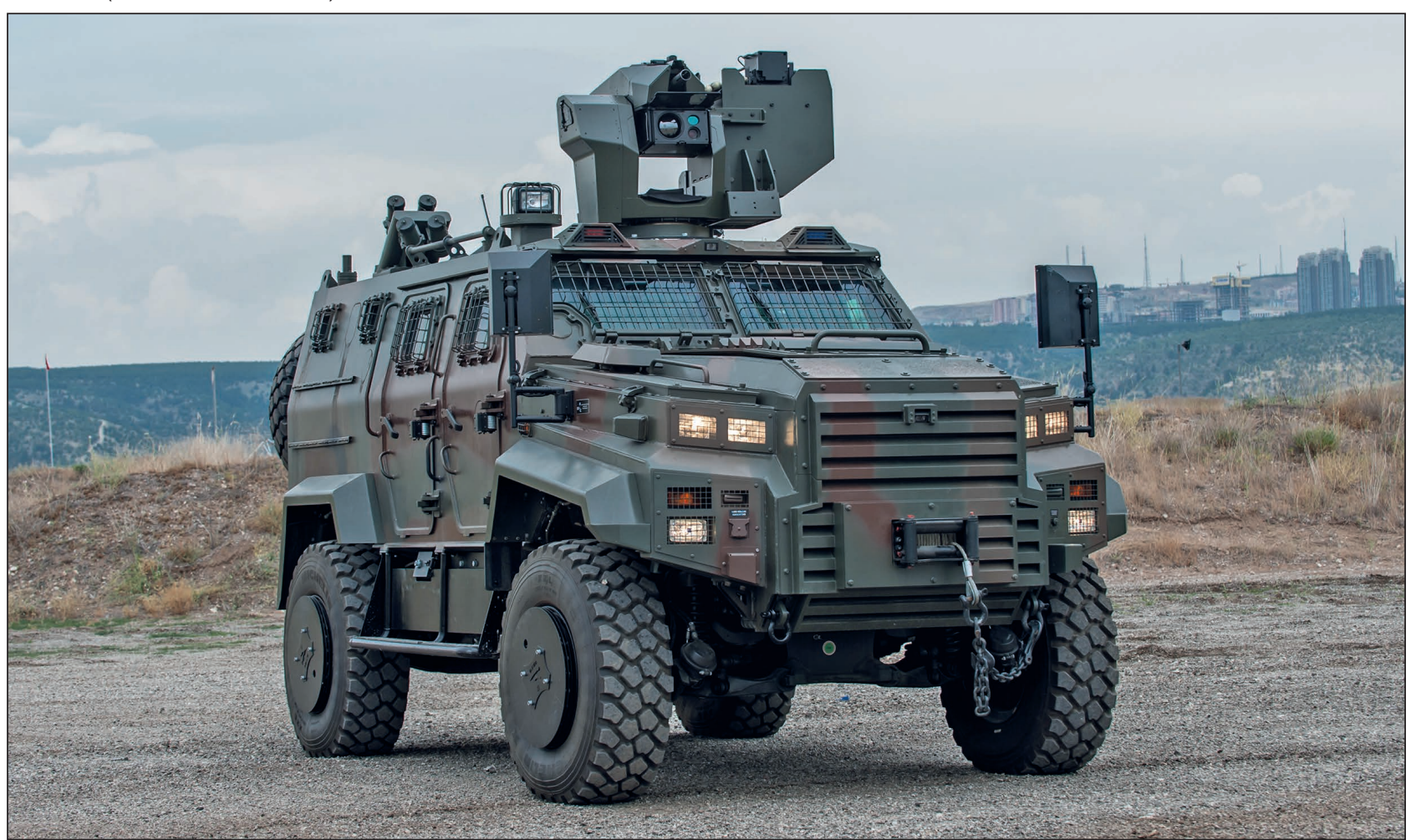


művet. Mivel ez a jármű - eltérően sok más gyártó MRAP kategóriás eszközeitől - nemcsak a küzdőteret védi az aknarobbanások és az oldalról érkező fenyegetések ellen, hanem a motorteret is védelemben részesíti, ezért a zárt beépítés miatt növelni kellett a teljesen körbepáncélozott motor hütését is, egy új, megnövelt kapacitású hűtőrendszer beépítésével. Természetesen az új, erősebb motor nagyobb teherbírású erőátviteli elemeket igényelt, amelynek nyomán a jármű teherbírása növekedett, e mellett a masszívabb futóművekkel és terepváltóval a terepakadályok is könnyebben leküzdhetővé váltak. A tesztelés során összegyűjtött adatok alapján megváltoztatták a futóművek rugózási karakterisztikáját, és a küzdőtérben elhelyezett ülések komfortosságán is javítottak. A módosítások érintették a fegyverrendszert is, így a korábbi SARP-torony helyett annak fejlettebb, több fegyver integrációjára is képes SARP-II változatát építették be az eszközbe. A török belbiztonsági erők részére 2015-2016. között leszállított 60 db eszközből mutat egy Block 2. verziójú járművet a 20. ábra.

A Block 2. változatú jármű kifejlesztésével nem állt le a gyár a fejlesztésekkel, és az egyre nagyobb eszközállomány által biztosított, folyamatosan érkező tapasztalatok alapján kezdték meg 2016-ban az Ejder Yalçin következő generációjának tervezését. A Block 3. verziónak nevezett szériára jellemző a tovább erősített aknavédelem kialakítása, amelyhez igazítva növelték a motor és az erőátviteli berendezések teherbírását, teljesítményét 278 kW-ra (375 LE-re), valamint a jármű további megbízhatósági és ergonómiai fejlesztéseket kapott. Egyik ilyen újdonság, hogy a jármű körüli tér figyelésére két darabbal több tükröt, mellső és hátsó keresőlámpákat, illetve több, új típusú kamerát telepítettek a jármű külső felületére körkörösen, amelyekkel a küzdőtérben helyet foglalók már nemcsak nappali körülmények között, hanem éjszaka is képesek a környezet figyelésére. Szintén a komfortot fokozta, de ezzel együtt a terepjárási képességek növelését is eredményezte az alkalmazott kerékabroncs méretének növelése, mert a korábbi 365/80 R 20 méretű kerekek helyére a 395/80 R 20 méretű, defekttűrő gumiabroncsokkal szerelt könnyűfém keréktárcsák kerültek. A személyzet és a jármű túlélési esélyeinek növelése érdekében belső tűzelfojtó, és külső, a gumiabroncsokra ható tűzoltórendszert kapott az eszköz, amely automatikusan és kézi üzemmódban is indítható.

Ez a széria olyan paraméterekkel rendelkezett, amely már felkeltette más országok fegyveres testületeinek ér-

\section{1. ábra. Egy Block 3. sorozatú Ejder Yalçin harcjármü} $12,7 \mathrm{~mm}$ ürméretű nehéz géppuskával szerelt Aselsan SARP II. típusú távirányított toronnyal (Forrás: Nurol Makina)

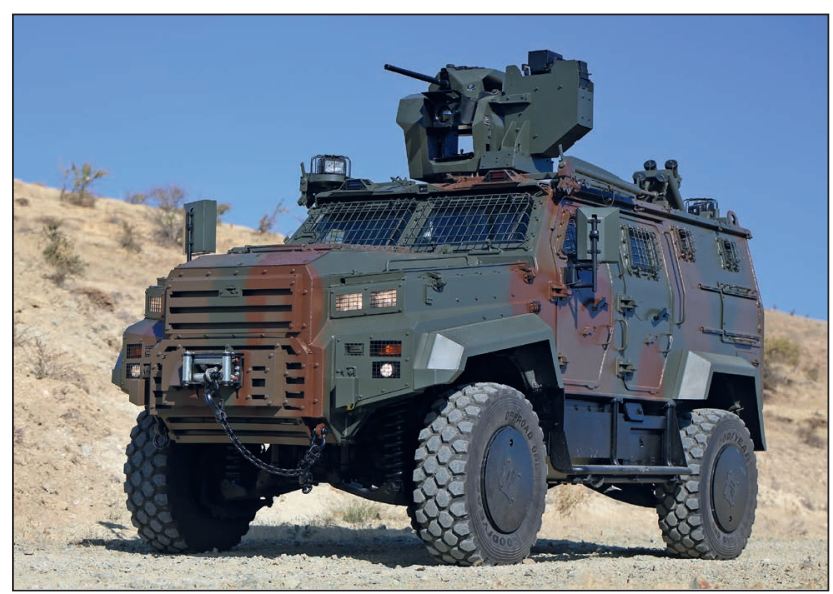

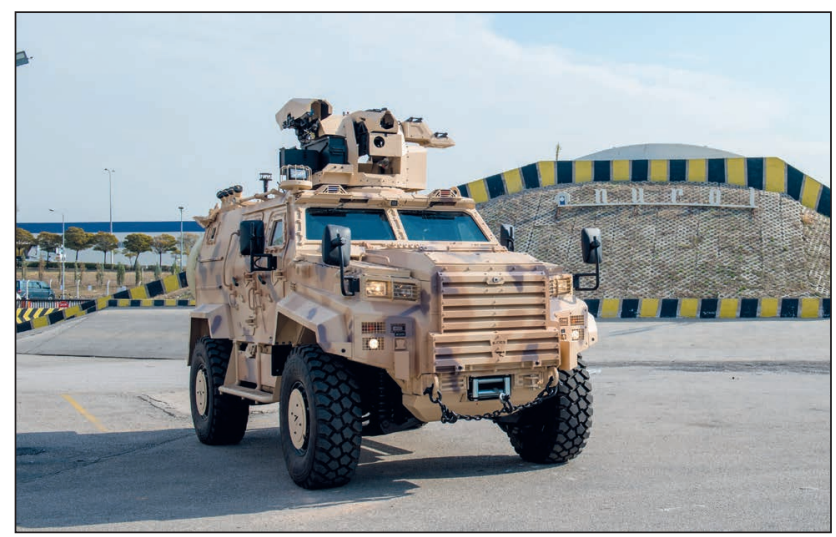

22. ábra. Páncéltörő rakétaindítóval szerelt Block 4. változatú Ejder Yalçin harcjármú a gyár tesztpályáján

(Forrás: Nurol Makina)

deklődését is, és a hazai beszerzéseken túl 800 db eszköz külföldre került. A jármű első külföldi megrendelője 2017ben Tunézia volt, amely először $75 \mathrm{db}$, majd a pozitív tapasztalatok alapján további 150 db eszközt rendelt meg. Szenegál 25 darabot rendelt, Katar fegyveres ereje pedig 342 eszközt, amelyekből több mint 200 db leszállítása 2020-ban megvalósult. Üzbegisztán 24 járművet rendelt, ám hazai gyártásban tervezi további 1000 db eszköz előállítását. Egy Block 3. szériájú jármú látható a 21. ábrán.

A következő generációváltásra 2018-ban került sor, amikor a nemzetközi tapasztalatokra építve, a gyár szakemberei kifejlesztették a Block 4. verziójú Ejder Yalçin harcjárművet (22. ábra). Az egyre bővülő tapasztalatok alapjain tovább erősítették a harcjármű motorjának hütési rendszerét, hogy melegebb, szélsőségesebb éghajlati körülmények között is tartósan működtetni lehessen a jármüveket. Ennek köszönhető a nagyobb teljesítményű hűtő-fűtő-légkondicionáló berendezés beépítése is, amellyel a küzdőtér ergonómiai követelményeinek jobban megfelelő környezet alakítható ki.

A vállalat, elsősorban az Ejder Yalçin harcjárművek értékesítéséből nyert tapasztalatok alapján felhagyott a más kerékelrendezésű járművek fejlesztésével, és kizárólag ezen járművek gyártására szakosodott. $A$ jelenleg gyártásban lévő változat a Block 4+, amelynek előálítását 2020ban kezdték, és amelyekből már több mint 500 db-ra elörendeléssel rendelkeznek, mind belföldi, mind külföldi

23. ábra. Az Ejder Yalçin Block 4+ harcjármű tű́zszerész manipulátor karral, kitolható árbócra szerelt felderítőkamerával és Aselsan SEDA lövésdetektáló rendszerrel felszerelt változata (Forrás: Nurol Makina)

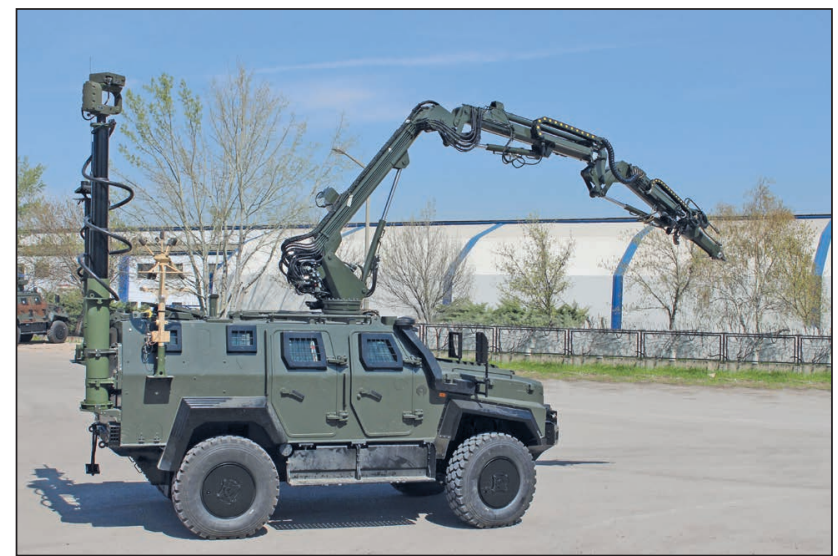


hadseregek részéről. Ebben a legutolsó verzióban tovább fejlesztették a kezelőszemélyzet kényelmi rendszereit, elsőként a légkondicionáló egységet, valamint az ergonómiai feltételeket növelték tovább. A vezető éjjellátó kamerarendszert kapott, és fokozták a hidraulikarendszer megbízhatóságát is.

A járműveknek több, feladatorientált típusa is ismert, mint a légvédelmi rakétákkal felszerelt változat, illetve a tűzvezető, páncéltörő, páncélozott mentő, vagy a tűzszerész robotkarral rendelkező műszaki/tűzszerész harcjármű. (23. ábra).

\section{GidRÁN, A MAGYAR SÁRKÁNY}

Már a fejlesztésekre vonatkozó stratégiai tervek kialakításának kezdeti szakaszában világossá vált, hogy a Zrínyi HHP célkitűzéseinek megvalósításához növelt páncélvédelemmel rendelkező multimoduláris terepjáró eszközökre is szükség lesz. Ezek az eszközök nem csupán a „páncélozott többcélú moduláris harcjárműképesség” kialakításához szükségesek, hanem más, az MH fejlesztésének gerincét képező programok, mint pl. a harckocsi- és tüzérképesség, vagy a gépesítettlövész-képesség megvalósulásához is elengedhetetlenek.

A hadmúveleti követelményeinket minden tekintetben kielégítő, a célnak leginkább megfelelő jármű kiválasztását egy alapos, és minden harcászati, műszaki és gazdasági körülményt figyelembe vevő piackutatás előzte meg, amely során a szakemberek áttekintették az ilyen kategóriájú járműveket gyártó, megfelelő gyártási tapasztalattal és kapacitással rendelkező országokat és vállalkozásokat.

Ezt követően kizárták a potenciálisan beszerzésre javasolt kerekes harcjárművek köréből azokat, amelyek gyártói a nagy távolság miatt gazdaságtalanul és nehézkesen tudnák biztosítani a (hadrafoghatóság érdekében fontos) folyamatos logisztikai ellátást. Szintén elvetették azoknak a járműveknek a beszerzését, amelyekből csak prototípus létezett, azaz a sorozatgyártásra alkalmas végső, kiforrott változat megjelenése éveket venne igénybe. Tekintettel a Zrínyi HHP keretében megvalósuló képességfejlesztések ütemezésére, olyan járművek beszerzésére volt szükség, amelyek legalább sorozatgyártásra érettek, és fejlesztésükbe valós harci tapasztalatok integrálására is sor került.

A Nurol Makina gyár terméke akkor került a Magyar Honvédség figyelmének középpontjába, amikor 2017. december elején, a Szlovák Fegyveres Erők meghívására egy szakértői csoport kiutazott a Zahorie tesztpályára, ahol a

24. ábra. Az Ejder Yalçin Block 3. verziója a Zahorie-ban tartott bemutatón (Fotó: Ocskay István)

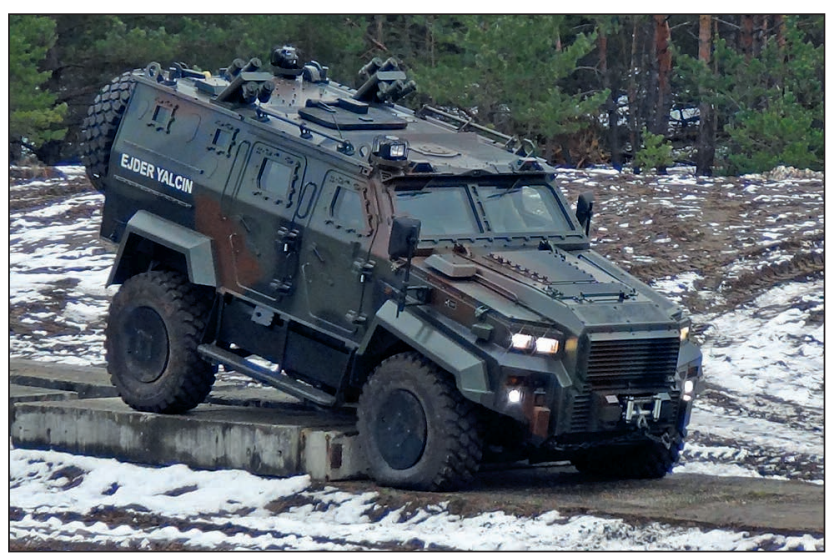

Szlovák tenderen induló $4 \times 4$ hajtásképletű páncélvédett eszközök gyártói, benevezett eszközeikkel a szlovák hadsereg részére tartottak bemutatót. A jármúvek között a szlovákok által gyártott Aligator-2, a török NUROL/FNSS és az Otokar vállalatok által forgalmazott Ejder Yalçin, PARS és Cobra II, a BAE System által gyártott Eagle-4, az Egyesült Arab Emírségek NIMR Automotive LLC és cseh VOP vállalatok együttműködésével gyártott $A j b a n$, a német KMW vállalat Dingo-2, valamint a Nexter által forgalmazott Renault Sherpa járművek képességeit vizsgálták. Már ekkor, a bemutatón megjelent 7 gyártóból a Nurol Makina vállalat eszköze nyújtotta a legdinamikusabb bemutatót, és ezzel felkeltette az érdeklődők figyelmét. (24. ábra)

A helyszíni szóbeli megbeszélések nyomán, 2017. december 14-én a Rába Jármúipari Holding Nyrt. pécsi tesztpályáján a török jármű gyártója egynapos dinamikus bemutatóval egybekötött prezentáció keretében megmutatta az $\mathrm{MH}$ szakemberei részére mire is képes a harcjármü. $A$ bemutatón részt vevő szakértők megállapították, hogy az eszközt nagyfokú ergonómia, mozgékonyság, védettség és variálhatóság jellemzi, így a kor műszaki követelményeinek megfelel, kategóriáában a többi eszközzel versenyképes.

Mindezeket összevetve, a potenciálisan beszerzésre javasolt kerekes harcjárművek köre jelentősen leszűkült, és a szakemberek összehasonlították a még versenyben maradt eszközök műszaki-technikai paramétereit. Végül a piackutatást végző bizottság arra a megállapításra jutott, hogy a mozgékonyság, a manőverezőképesség, az integrálható fegyverrendszerek, az elérhető konfigurációk, illetve a legfőbb prioritásként kezelt ballisztikus, illetve akna elleni védettség figyelembevételével a török Nurol Makina által gyártott Ejder Yalçin $(4 \times 4)$ típusú Block 4. verziójú jármű beszerzése javasolt. A döntés megszületését, és egy sikeres beszerzési eljárást követően, 2018. október 5-én a megrendelő és a gyártó aláirta azt a keretszerződést, amely megteremtette a kezdeti feltételeit annak, hogy a Zrínyi HHP keretében beszerezzék az MH fejlesztéséhez szükséges páncélozott, többcélú, moduláris, növelt aknavédelemmel rendelkező kerekes harcjárműveket. Ezen eszközök mellett az aláírt szerződés tartalmazza a gyár kínálati palettáián szereplő, akkor még csak tesztelési fázisban lévő NMS ${ }^{25} 4 \times 4$ kerékképletű „kistestvér” beszerzését is, amely jellemzően a különleges műveleti erők által hazánkban alkalmazott HMMWV jármű leváltását teszi lehetővé. Az akkor még név nélkül szereplő eszköz azóta megkapta az NMS Yörük, azaz a Nomád nevet.

2019 májusában, a Budaörsi Repülőtéren rendezett bemutatón mindkét eszközt láthatta az érdeklődő közönség.

25. ábra. Az Ejder Yalçin harcjármű küzd a Rába Nyrt. pécsi tesztpályájának eltolt szinuszaival (Fotó: Ocskay István)

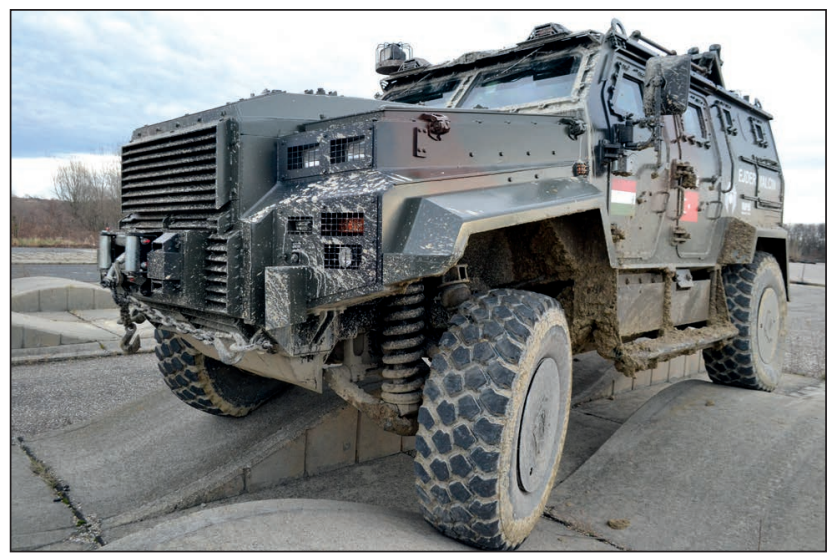




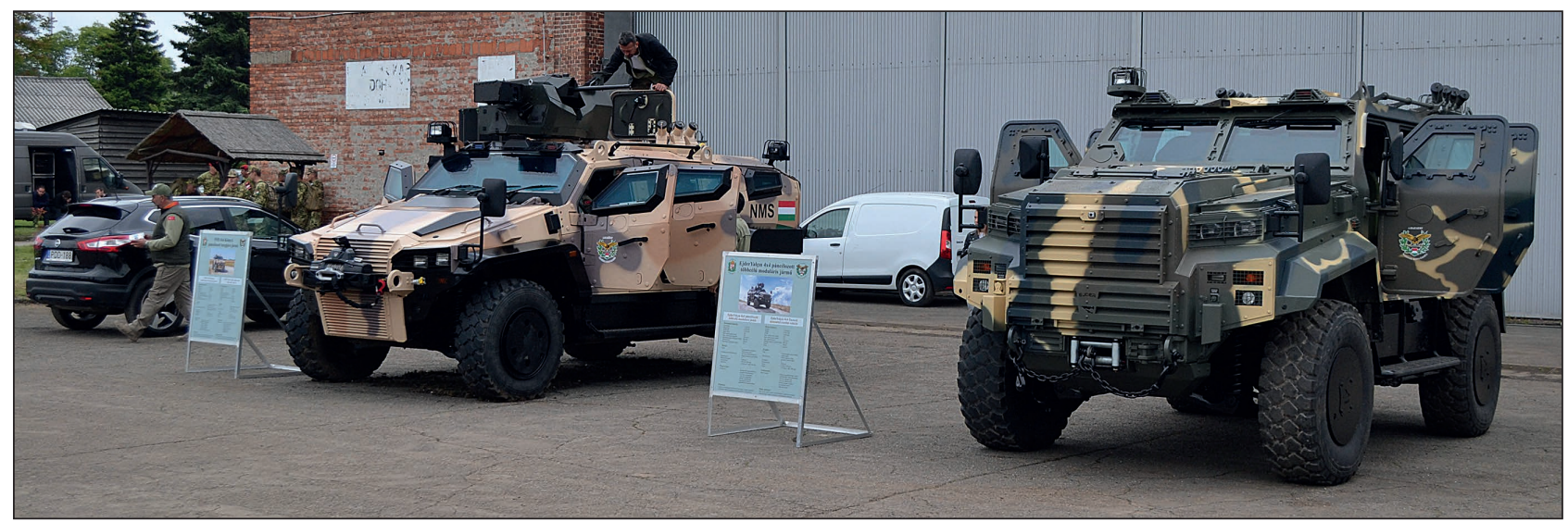

26. ábra. Az NMS Yörük és az Ejder Yalçin harcjárművek a 2019-es budaörsi haditechnikai bemutatón (Fotó: Ocskay István)

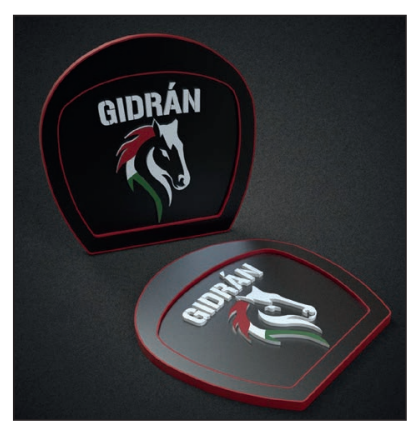

27. ábra. A Gidrán harcjármú logójának elfogadott terve (Fotó: Ocskay István)
Az Ejder Yalçin már az új normáknak megfelelő álcázó színekkel mutatkozott be, amely színkombináció azóta már visszaköszönt a 2020 júliusában bemutatkozó Leopard 2A4HU harcjármüveken is.

Az Ejder Yalçin Block 4+ jármü főbb méreteit és a legfontosabb általános műszaki-technikai paramétereit az 1. táblázat foglalja össze.

Mivel az Ejder Yalçin név a magyarok számára nehezen kiejthető, másrészt az új beszerzésű eszközök „meghonosítása" érdekében javaslat született a harcjármú elnevezésére, amely Gidrán ${ }^{27}$ néven kerül be az $\mathrm{MH}$ eszközparkjába. A nemes profilvágású, erős csontozatú, középnehéz, szilárd szervezetű és széles körben alkalmazható ló méltó jelképe a magyar igények szerint kialakított Ejder Yalçin járműveknek. A névválasztáshoz kapcsolódóan, a gyártó lófejet ábrázoló logóra cseréli a korábbi sárkány rajzolatú logóját. (27. ábra)

A Magyar Honvédség igényei szerint kialakított jármü általános műszaki-technikai paraméterei alapvetően megegyeznek az előzőekben ismertetett Ejder Yalçin Block 4+ harcjármű adataival, vagy csak kis mértékben térnek el attól. Eltérés jellemzően ott keletkezik, ahol az MH-ban rendszeresített eszközök, fegyverek elhelyezése miatt arra szükség volt. A Gidrán főbb méreteit a 28. ábra mutatja be.

28. ábra Az Ejder Yalçin Block 4+ harcjármü föbb méretei mm-ben (Forrás: Gidrán kezelési utasítás)
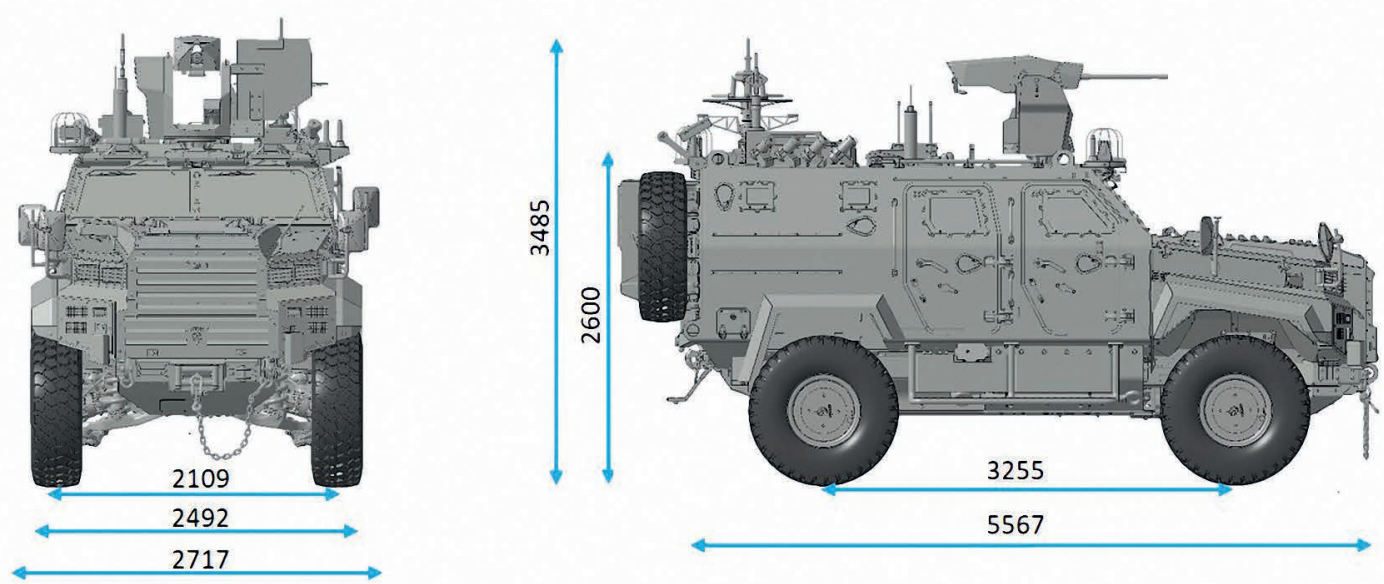

5917

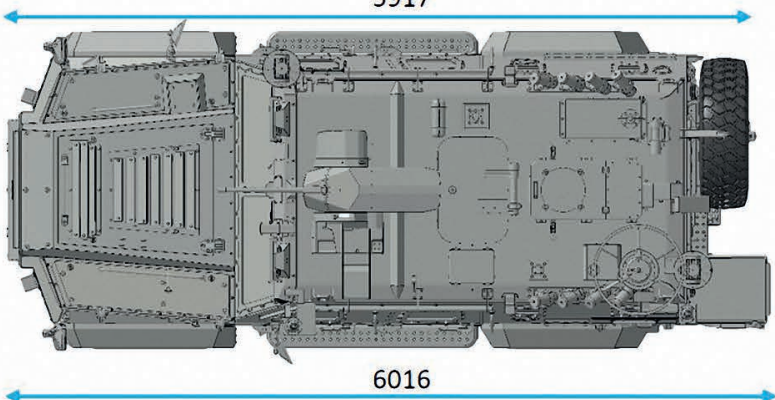


1. táblázat. Az Ejder Yalçin Block 4+ verzió általános müszaki-technikai paraméterei (Forrás: a szerzők szerkesztése)

\begin{tabular}{|c|c|c|}
\hline \multirow{7}{*}{ Főbb méretek } & Hosszúság (mm) (tükrök nélkül) & 6016 \\
\hline & Szélesség $(\mathrm{mm})$ & 2492 \\
\hline & Magasság (mm) (a lövegtoronytól) & 3345 \\
\hline & Nyomtávolság (mm) & 2109 \\
\hline & Hasmagasság (mm) & 473 \\
\hline & Első terepszög $\left(^{\circ}\right)$ & 44 \\
\hline & Hátsó terepszög $\left(^{\circ}\right)$ & 46 \\
\hline \multirow{3}{*}{ Tömegadatok } & Saját tömeg (lövegtorony nélkül) [kg] & 15200 \\
\hline & Tömeg harcképes állapotban (lövegtoronnyal) (kg) & 16700 \\
\hline & Terhelhetőség (kg) & 4000 \\
\hline \multirow{2}{*}{ Páncélvédettség } & Ballisztikai & EN 1522 FB7 \\
\hline & Aknavédelem & STANAG 4569 AEP 2 Level 2b/4a \\
\hline \multirow{5}{*}{ Erőforrás } & Típus & Cummins ISL9 E3 8.9 I 6 h. dízel, turbófeltöltős \\
\hline & Lökettérfogat $\left(\mathrm{cm}^{3}\right)$ & 8900 \\
\hline & $\begin{array}{l}\text { Maximális teljesítmény } \\
21001 / \text { min fordulatszámon (kW) }\end{array}$ & 275 \\
\hline & $\begin{array}{l}\text { Maximális nyomaték 1100-1400 1/min } \\
\text { fordulatszámon }(\mathrm{Nm})\end{array}$ & 1550 \\
\hline & Környezetvédelmi besorolás & EURO 3 \\
\hline \multirow{3}{*}{ Erőátvitel } & Hajtáslánc & $\begin{array}{l}\text { Egyenlő erőelosztás, tengelyek és kerekek } \\
\text { között zárható, állandó } 4 \times 4 \text {-es hajtás }\end{array}$ \\
\hline & Sebességváltómü & $\begin{array}{l}\text { Allison 3200SP, hatsebességes automata, } \\
\text { retarderrel rendelkezö }\end{array}$ \\
\hline & Osztómű & MTC 60/420, központi differenciálzárral rendelkező \\
\hline \multirow{6}{*}{ Járómű } & Futómű & $\begin{array}{c}\text { Független kerékfelfüggesztés dupla lengőkarral, } \\
\text { tekercsrugóval és lengéscsillapítóval }\end{array}$ \\
\hline & Hajtott kerekek száma $(\mathrm{db})$ & 4 (állandó) \\
\hline & Maximális sebesség úton $(\mathrm{km} / \mathrm{h})$ & 120 \\
\hline & Gumiabroncs & $\begin{array}{l}\text { Michelin 395/85R20 XZL, defekttürö (Finebel A 25), } \\
\text { központi kerékfúvató }\end{array}$ \\
\hline & Fékek & $\begin{array}{l}\text { kétkörös, elektronikusan vezérelt légfék, } \\
\text { Westing jellegü rögzítőfék a hátsótengelyen. } \\
\text { Minden keréken léghütésű tárcsafék. }\end{array}$ \\
\hline & Rásegítő rendszerek & ABS és motorfék \\
\hline \multicolumn{2}{|c|}{ Hatótávolság $(\mathrm{km})$} & 700 \\
\hline \multicolumn{2}{|c|}{ Üzemanyagtartály kapacitása (liter) } & 200 \\
\hline \multicolumn{2}{|c|}{ Gázlóképesség (mm) } & 900 \\
\hline \multicolumn{2}{|c|}{ Árokáthidaló képesség (mm) } & 1100 \\
\hline \multicolumn{2}{|c|}{ Lépcsőmászó képesség (mm) } & 500 \\
\hline \multicolumn{2}{|c|}{ Fordulási sugár $(\mathrm{m})$} & 7,75 \\
\hline \multicolumn{2}{|c|}{ Maximális oldaldőlés (\%) } & 30 \\
\hline \multicolumn{2}{|c|}{ Emelkedő leküzdő képesség (\%) } & 60 \\
\hline \multicolumn{2}{|c|}{ Működési hőmérséklet $\left({ }^{\circ} \mathrm{C}\right)$} & $-32 /+55$ \\
\hline \multicolumn{2}{|l|}{ Felépítmény } & $\begin{array}{c}\text { Önhordó „V” monocoque kialakítású páncéltest } \\
\text { hegesztett páncéllemezekből }\end{array}$ \\
\hline \multicolumn{2}{|c|}{ Szállítható személyek száma (fő) } & $3+6$ \\
\hline \multicolumn{2}{|c|}{ Elérhető konfigurációk } & $\begin{array}{l}\text { 1. parancsnoki } \\
\text { 2. páncéltörő } \\
\text { 3. légvédelmi } \\
\text { 4. felderítő } \\
\text { 5. személyszállító } \\
\text { 6. határvédelmi felderítő- és biztonsági jármű } \\
\text { 7. páncélozott harcjármű } \\
\text { 8. EW26, zavaró jármű } \\
\text { 9. akna-, illetve IED-felderítő és tűzszerész jármű } \\
\text { 10. ABV-felderítő gépjármű, } \\
\text { 11. radarral rendelkező jármű } \\
\text { 12. mentőjármű } \\
\text { 13. rendfenntartó jármű }\end{array}$ \\
\hline \multicolumn{2}{|c|}{ Fegyverrendszer-integrálási lehetőségek } & $\begin{array}{l}\text { Távvezérlésű stabilizált fegyverrendszer. } \\
\begin{array}{ll}\text { 1. } 7,62 \mathrm{~mm} \text { géppuska } & \text { 5. légvédelmi rendszer } \\
\text { 2. } 12,7 \mathrm{~mm} \text { géppuska } & \text { 6. páncéltörő rendszer } \\
\text { 3. } 40 \mathrm{~mm} \text { gránátvető } & \end{array}\end{array}$ \\
\hline
\end{tabular}




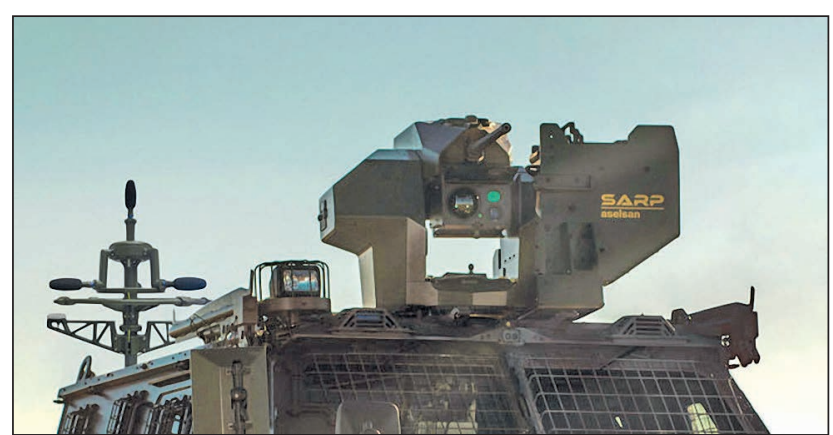

29. ábra. Az Aselsan vállalat SEDA lövésérzékelője, illetve SARP II távirányított tornya M2 12,7 × 99 mm-es nehéz géppuskával szerelve egy Ejder Yalçin tetőpáncélján [20]

Elmondható, hogy az MH igényeinek megfelelően kialakítandó típusvariációk mindegyike rendelkezni fog a motortól függetlenül működtethető kiegészítő energiaforrással ${ }^{28}$, amely leállított járműmotornál is biztosítja a beépített rendszerek (fegyverrendszer, kommunikáció, felderítőeszközök) csendes, üzemanyagtakarékos és tartós működését. Az APU egységet a jármü farpáncélján, bal oldalon helyezik el. A dízelüzemű kiegészítő fütőberendezés hideg időben a jármű motorját és a küzdőteret egyaránt felmelegíti, ugyanakkor a kollektív vegyivédelmi berendezések (CBRN szűrő, túlnyomás biztosítása) működése esetén is biztonságosan üzemeltethető klímaberendezés meleg időben biztosítja a megfelelő hőmérsékletet. A járművek elején elhelyezett csörlőberendezés lehetővé teszi az önmentést, az automatikus tűzoltó rendszer pedig már a tűz keletkezésének pillanatában a jármű motortérben és belsejében egyaránt elfolytja a tüzet.

A járművek alapvetően távvezérlésű, stabilizált fegyverrendszerrel és ködgránátvetővel készülnek, a megfelelő álcázást pedig a jármű festésén kívül a kibocsájtott hő- és elektromágneses kisugárzás minimalizálása biztosítja. A Gidrán esetében a jármű távirányított fegyverrendszerét ${ }^{29}$ a szintén török Aselsan vállalt gyártja SARP II néven. A szenzorok sokaságának köszönhetően a fegyverrendszer nappal, éjjel és korlátozott látási viszonyok között egyaránt nagy biztonsággal használható, a moduláris kialakítás pedig lehetővé teszi számos eltérő méretű és típusú géppuska, valamint gránátvető használatát.

A stabilizált, növelt képességű, távirányított torony felderítő-, tűzvezető rendszere rendelkezik nappali és éjszakai

30. ábra. Az első beérkezett Gidrán harcjármúvek az MH ARB telephelyén (Fotó: HM Zrínyi Nonprofit Kft./honvedelem.hu)

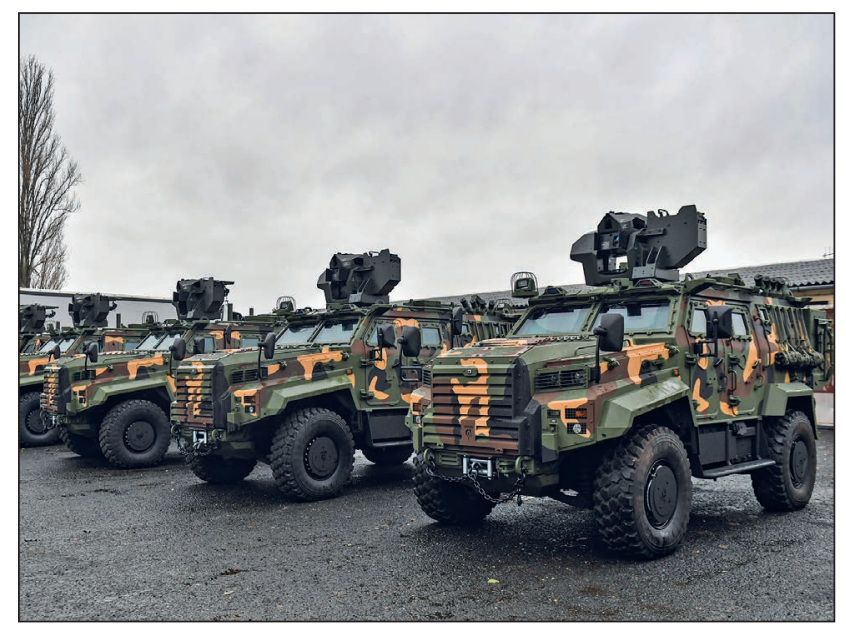

csatornával, hozzá kapcsolható automatikus célrávezető rendszerrel és lézertávmérővel. Az integrálható fegyverek választéka széles, a 7,62 mm-es géppuskától a 40 mm-es gránátvetőig mindegyiket befogadhatja a fegyverbölcső. A magyar fél számára a 12,7 × 99 mm-es NATO-lőszert tüzelő M2 nehéz géppuska beszerelése tervezett $400 \mathrm{db}$-os kihelyezett lőszerkészlettel. A szükség esetén manuálisan is mozgatható torony magassága $70 \mathrm{~cm}$, tömege $165 \mathrm{~kg}$, amely nem tartalmazza a fegyver- és a lőszerjavadalmazás tömegét. $A 360^{\circ}$-ban körbe forgatható toronyban függőlegesen $-30^{\circ}$ és $+60^{\circ}$ között mozgatható a géppuska.

Szintén a jármű felszerelése lesz az Aselsan vállalat SEDA lövésdetektáló rendszere, amelynek stacioner, kihelyezhető és járműre telepíthető változata is létezik. A detektáló rendszer érzékeli a szuperszonikus sebességgel közeledő lövedékek irányát és sebességét, amelyet összevetve a GPS koordinátákkal, mindenfajta időjárási körülmények között képes kiszámítani a fegyver/lövő tartózkodási helyét. Egy, az Ejder Yalçinra a SARP II toronnyal együtt integrált érzékelőt mutat a 30. ábra. [16]

A 2020 novemberében beérkezett 10 darab, illetve a keretszerződés ideje alatt beszerzendő további Gidrán harcjárművekkel az MH-ban jelentős képességnövekedésre kerül sor, amellyel meghonosodhat a növelt páncélvédelemmel rendelkező harcjárművek kultúrája, és bízunk abban, hogy ez a kultúra még sokáig, több évtizeden át az $\mathrm{MH}$ része lehet.

A Haditechnika 2021/4. szám mellékleteként kiadott poszter az Ejder Yalçin Block 4+ verziót ábrázolja.

\section{HivATKOZOTT IRODALOM}

[15] "The Romanian RN-94 6×6 wheeled Armoured Personnel Carrier" TankNutDave.com, https:// tanknutdave. com/the-romanian-rn-94-6x6-wheeledarmoured-personnel-carrier (Letöltve: 2021.3.17.);

[16] „SEDA Gunshot Detection System” ASELSAN https://www.aselsan.com.tr/ASELSAN_SEDA Gunshot_Detection_System_1877.pdf (Letöltve: 2021.3.17.);

[17] Forrás: https://www.carthrottle.com/post/m096Bc/ (Letöltve: 2021.3.17.);

[18] Forrás: https://www.pinterest.at/ pin/510173464022871827 (Letöltve: 2021.3.17.);

[19] Forrás: https://en.topwar.ru/57844-legkie-mashiny-vperelomnyy-moment-chast-1-iz-3-ne-gotovo.html (Letöltve: 2021.3.17.);

[20] Forrás: https://in.pinterest.com/ pin/646899933963756281/ (Letöltve: 2021.3.17.).

\footnotetext{
JEGYZETEK

21 Jelentése: sárkány.

22 Special Operational Forces.

23 Stabilized Advanced Remote (Weapon) Platform - stabilizált korszerűsített távirányított fegyverplatform.

24 A retarder tartós fék, amelyre azért van szükség, mert a kerékre ható dob- vagy tárcsafékek a tartós használat során felmelegszenek, csökken a fékezés hatásossága, így a jármű nem alkalmas a hosszú lejtőkön szükséges tartós fékezésre.

25 Nurol Makina ve Sanay A. Ș.

26 Electronic Warfare - elektronikai hadviselés.

27 Gidrán, a 19. század elejére visszavezethető múlttal rendelkező, magyar tenyésztésű középnehéz hátas- és igásló.

28 APU - Auxilary Power Unit.

29 RCWS - Remote Controled Weapon Station.
} 